\title{
Perancangan Arsitektur Integrasi Sistem Informasi Menggunakan Metode Service Oriented Analysis And Design (SOAD) (Studi Kasus : Politeknik LPKIA Bandung)
}

\author{
Tri Ramdhany \\ Program Studi Sistem Informasi \\ STMIK LPKIA Bandung, Jl. Soekarno Hatta NO. 456 Bandung \\ Email : triramdhany@gmail.com
}

\begin{abstract}
ABSTRAK
Seiring dengan perkembangan teknologi informasi, aplikasi dan platform yang digunakan oleh departemen-departemen dan unit pendukung pada perguruan tinggi yaitu Politeknik LPKIA Bandung menjadi beragam. Oleh karena itu diperlukan sebuah metode yang digunakan untuk melakukan integrasi sistem informasi yang berjalan, metode tersebut adalah metode Service Oriented Analysis and Design (SOAD). Merupakan sebuah metode perancangan sistem yang mengelompokan proses bisnis menjadi sekumpulan service melalui dua tahapan utama yaitu analisis service dan desain service.

Untuk memperoleh service yang responsive terhadap proses bisnis yang berlangsung, digunakan juga pendekatan Object Oriented Analysis and Design (OOAD). Yaitu use case diagram untuk memetakan kandidat service entity-centric business service dan kandidat service task-centric business service dan menggunakan class diagram untuk menentukan arsitektur data dari kandidat service-service yang terpilih menjadi desain service final.

Hasil akhir yang diperoleh dari tahapan analisis service dan desain service tersebut yaitu berupa arsitektur sistem informasi dan arsitektur data berorientasi service yang menjadi dasar dalam menentukan rancangan arsitektur integrasi sistem informasi di Politeknik LPKIA Bandung
\end{abstract}

Kata Kunci : Service Oriented Analysis and Design, Business Process Modeling Notation, Object Oriented Analysis and Design

\begin{abstract}
As information technology grows, the applications and platforms used by the department and supporting unit in Politeknik LPKIA are becoming more diverse. Therefore we need a method that is used to integrate information systems that are running, the method is the Service Orientation Analysis and Design (SOAD) method. Is a system design method that classifies business processes into a group of services through two main stages, namely service analysis and service design.

To obtain a responsive service from the on-going business process an Object Oriented Analysis and Design (OOAD) is also being use. It is a use case diagram to map the service entity-centric business service and task-centric business service candidates and using a class diagram to determine architecture data from the selected service candidates to become a final service.

From the current final design service it is devided into 3 layers, 1 service at orchestration service layer which role is to manage services needed for every application;
\end{abstract}


29 services at business service layer which role is to provide and publish service for orchestration service layer; and 3 service at application service layer which role is to access database. Apart from that, to ensure the final design service suitable with the ongoing business process, an identification of service operation based on Business process Modeling Notation is conducted.

The final result gained from the analysis service and design service steps are an information system architecture and service oriented data architecture which become the base in determining the integrated information system architecture design at Politeknik LPKIA Bandung.

Keywords: Service Oriented Analysis and Design, Business Process Modeling Notation, Object Oriented Analysis and Design.

\section{PENDAHULUAN}

Perkembangan teknologi informasi menyebabkan pembangunan sistem infomasi menggunakan berbagai macam platform. Hal ini tentu menyebabkan kesatuan antar layanan menjadi rendah dan menyebabkan munculnya pulau-pulau informasi yang terpisah - pisah (stovepipe system). Hal ini juga berimbas kepada sektor pendidikan, Pada prinsipnya terdapat 3 proses inti yang ada dalam pendidikan tinggi yaitu: pengajaran, penelitian dan pelayanan kepada masyarakat. Proses tersebut didukung oleh aktivitas pendukung seperti aktivitas administrasi, aktivitas akademik lainnya, keuangan, penggunaan sarana dan prasarana, pengelolaan sumber daya manusia baik dosen maupun staff administrasi.

Perkembangan teknologi informasi dan komunikasi juga memunculkan kendala baru yaitu adanya perbedaan kemampuan sumber daya manusia dalam mengolah dan memanfaatkan teknologi, serta munculnya aplikasi dengan format dan platform yang berbeda-beda yang digunakan oleh departemen dan unit pendukung pada perguruan tinggi. Hal tersebut menyebabkan data yang sama pada tempat yang berbeda (redundancy) dan informasi yang sama pada aplikasi yang berbeda (incompatibility). Aplikasi yang digunakan dimasa lalu tidak compatible dengan aplikasi saat ini, sedangkan data dan informasi masa lalu masih digunakan dalam proses bisnis saat ini. Untuk mengatasi masalah tersebut, maka perlu dilakukan modifikasi pada aplikasi bahkan membangun ulang sistem informasi yang sudah ada, namun akibatnya tentu berdampak pada pengeluaran biaya yang cukup besar.

Berdasarkan masalah diatas maka diperlukan sebuah metode arsitektur integrasi sistem informasi sehingga di peroleh model perancangan perangkat lunak dengan memodularisasi sistem informasi menjadi service dengan cara mengelompokan 
proses bisnis perusahaan metode tersebut adalah Service Oriented Analysis and Design (SOAD).

\subsection{Identifikasi Masalah}

Sesuai dengan apa yang telah dipaparkan dalam latar belakang dapat diidentifikasi masalah-masalah sebagai berikut:

1. Bagaimana merancang service yang sesuai dengan kebutuhan proses bisnis di Politeknik LPKIA Bandung dengan menggunakan metode SOAD?

2. Bagaimana merancang blueprint integrasi sistem informasi berbasis Service Oriented Architecture (SOA) menggunakan metode Service Oriented Analysis and Design (SOAD) pada institusi pendidikan Politeknik LPKIA Bandung?

\subsection{Tujuan}

Adapun tujuan yang ingin dicapai dalam penulisan tesis ini adalah sebagai berikut:

1. Mendapatkan gambaran mengenai desain service yang dibutuhkan oleh user pada proses bisnis yang berhubungan dengan operasional pendidikan.

2. Terbentuknya blueprint integrasi sistem informasi Menggunakan metode Service Oriented Analysis And Design (SOAD)

\subsection{Landasan Teori}

Model arsitektur integrasi sistem informasi yang menggunakan metode SOAD yang dikeluarkan oleh IBM menjelaskan bahwa SOAD ini merupakan perancangan yang dilakukan top-down, yaitu dengan menganalisa kebutuhan bisnis menjadi service, kemudian mendefinisikan kebutuhan komponen service dan diimplementasikan dalam sistem.

Dalam melakukan perancangan SOAD dibagi menjadi 3 domain (IBM, 2004) yang diuraikan sebagai berikut:

1. Domain bisnis, menjelaskan proses bisnis dan fungsinya dalam sebuah organisasi dapat digambarkan menggunakan BPM, BPM (Business Process Management) sendiri merupakan disiplin ilmu untuk memodelkan, mengotomatisasi dan mengoptimasi proses bisnis sehingga dapat meningkatkan tingkat profitability, tool yang dapat digunakan dalam menggambarkan proses bisnis adalah BPMN (Business Process Modeling Notation). BPMN sendiri merupakan salah satu standar untuk memodelkan webservice dan proses webservice dengan BPMN ini bisnis proses yang cukup sulit dapat dipetakan dengan lebih mudah dipahami 
(Owen and Raj, 2003: 3). BPMN pada tesis ini digunakan dalam melakukan identifikasi proses bisnis dan menentukan proses dari kandidat service operation.

2. Domain arsitektur menjelaskan arsitektur sistem yang akan dibangun dapat digambarkan dengan enterprise architecture. EA menurut (Sarno and Hardiyanti 2010: 145) menyediakan gambaran yang lengkap mengenai sebuah isasi secara jelas dan komprehensif baik itu dari visi, misi, fungsi dan tujuan maupun sistem-sistem yang mendukung terlaksananya fungsi organisasi, EA sendiri terdiri dari 4 arsitektur yaitu arsitektur bisnis, aplikasi, informasi dan teknologi. Pada tesis ini arsitektur sistem yang dibangun adalah arsitektur sistem berorientasi service sehingga menjadi model integrasi sistem informasi.

3. Domain aplikasi menjelaskan penerapan fungsionalitas sistem yang telah dirancang, dapat dilakukan dengan pendekatan Object Oriented Analysis and Design (OOAD) atau Object Oriented Modeling (OOM). OOM sendiri merupakan metode analisis yang melihat requirements dari sudut pandang kelas-kelas dan obyek yang ditemui dalam ruang lingkup permasalahan yang mengarahkan arsitektur software yang didasarkan pada manipulasi obyek-obyek sistem atau subsistem (Booch, Rumbaugh, Jacobson, 1998: 20). Pendekatan OOM pada tesis ini yaitu menggunakan use case diagram dalam memetakan kandidat service dan menggunakan class diagram untuk menentukan arsitektur data dari desain service.

Dapat disimpulkan bahwa pendekatan SOAD merupakan gabungan dari implementasi beberapa pendekatan yaitu business process management, enterprise architecture, dan object oriented modeling, untuk lebih jelasnya dapat ditunjukan pada gambar 1. 


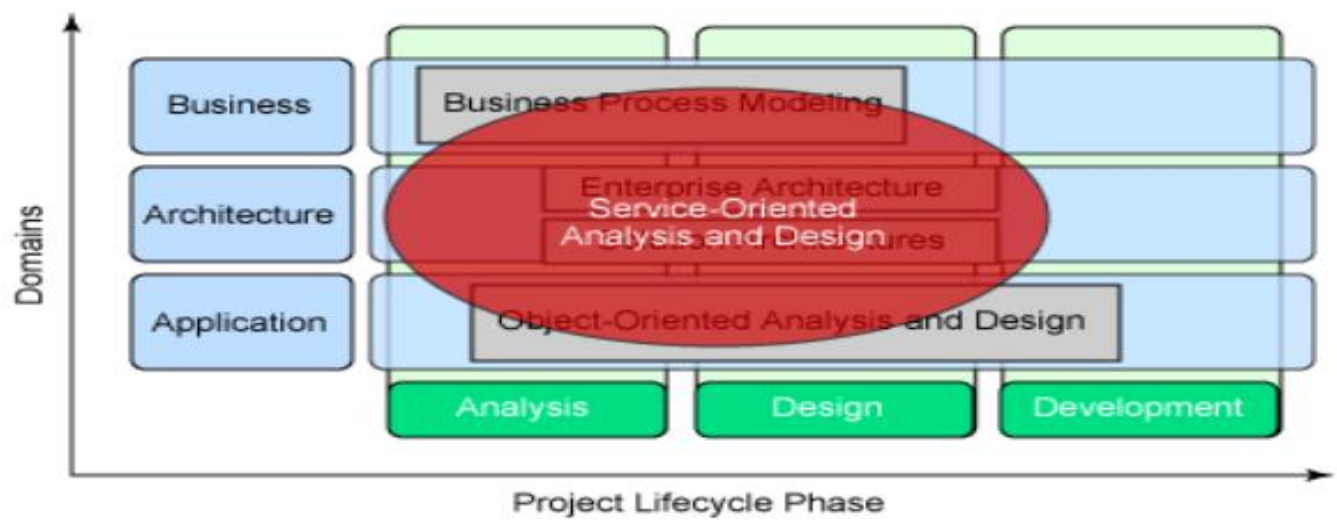

Gambar 1: Domain Pembentuk SOAD (IBM, 2004)

Berdasarkan uraian yang telah dijabarkan sebelumnya mengenai SOAD, maka berikutnya dijabarkan lebih lanjut mengenai fase-fase atau tahapan yang harus dilakukan dalam SOAD sehingga dapat diperoleh analisis kebutuhan sistem maupun rancangan berbasis service oriented.

fase awal dalam pengembangan Integrasi sistem informas adalah identifikasi dan analisis service, tujuan yang ingin dicapai dalam service oriented analysis adalah sebagai berikut (Erl, 2005: 198):

1. Mendefinisikan kandidat-kandidat service yang akan ada.

2. Mengelompokan kandidat service yang telah didefinisikan sesuai dengan konteks logik masing-masing.

3. Mendefinisikan batasan antar service sehingga tidak terjadi overlap antar service.

4. Mengidentifikasi logik yang terkandung didalam service yang berpotensi untuk digunakan kembali.

5. Memastikan logik dari setiap service sesuai dengan tujuan dan fungsionalitas dari service yang bersangkutan.

6. Mendefinisikan desain awal komposisi service.

Menurut (Erl, 2005: 198) ada beberapa langkah yang harus dilakukan dalam tahap ini adalah sebagai berikut:

1. Mendefinisikan kebutuhan bisnis, kebutuhan bisnis ini bisa dimodelkan dengan BPM (Business Process Management).

2. Mengidentifikasi sistem yang telah ada, yaitu melakukan pendataan sistem yang ada pada lingkungan operasional aplikasi yang mempunyai kemungkinan untuk berinteraksi atau memberikan pengaruh terhadap aplikasi yang lain. 
3. Memodelkan kandidat-kandidat service yang disediakan oleh aplikasi, kandidat service yang dimaksud akan berbentuk business service, application service, dan orkestrasi logik dari process service.

Setelah menentukan kandidat service yang telah dilakukan pada tahap analisis, langkah selanjutnya adalah melakukan desain kongkrit dari kandidat service yang telah ada dan mengimplementasikannya dalam sebuah komposisi yang membentuk proses bisnis, tujuan tahapan service oriented design (Erl, 2005: 236) adalah sebagai berikut:

1. Bagaimana mendefinisikan secara fisik interface service dari kandidat service yang didapatkan dari tahapan service oriented analysis.

2. Karakteristik SOA apa yang akan diimplementasikan.

3. Standar apa saja yang perlu ditetapkan oleh aplikasi SOA yang akan dibuat.

Tujuan dari yang akan dicapai pada fase service oriented design yang dijabarkan di atas dijabarkan menjadi tindakan-tindakan yang lebih detail (Erl, 2005: 236) sebagai berikut:

1. Menentukan bagian utama dari sistem.

2. Menentukan standar apa saja yang akan dipakai dalam sistem yang akan dibuat.

3. Membuat batasan yang jelas dari sistem yang akan dibuat.

4. Mendefinisikan interface service.

5. Mengidentifikasi kemungkinan service, komposisi service yang mungkin muncul.

6. Menerapkan prinsip service orientation.

7. Mengeksplorasi dukungan untuk sistem SOA lainnya.

Ada 3 langkah utama yang harus dilakukan (Erl, 2005:237):

1. Mendekomposisi SOA, yaitu dengan mendefinisikan teknologi yang akan digunakan.

2. Service design, mencakup penentuan hasil akhir service berupa entitiy-centric business service, task-centric business service dan application service berdasarkan kandidat service yang diperoleh dari tahapan analysis service oriented. 
3. Business process design, proses bisnis yang didesain pada tahapan ini adalah proses bisnis untuk orchestration layer, dengan menentukan logic workflow dari SOA.

Dalam membangun desain dari entity-centric business service, task-centric business service dan application service, langkah-langkah yang harus dilakukan adalah sebagai berikut (Erl, 2005: 237):

1. Menentukan service mana dalam tahapan analisis yang akan ditentukan.

2. Menentukan schema yang digunakan agar service dapat saling bertukar informasi dengan mengirimkan pesan.

3. Mendefinisikan interface dari service, interface disini berupa port. Melalui port tersebut service dapat menerima dan mengirim, Mengimplementasikan prinsipprinsip SOA seperti reusability, autonomy, statlessness, dan discoverability.

4. Mecari ulang interface service yang telah ditentukan.

5. Mengembangkan lebih lanjut operasi yang ada dalam suatu service.

6. Mengidentifikasi batasan teknis yang ada.

7. Mengidentifikasi service lain yang dibutuhkan, apabila service yang didesain bersifat kompleks dan merupakan hasil komposisi dari banyak service.

\section{METODE PENELITIAN}

Untuk melakukan perancangan integrasi sistem informasi maka perlu ditentukan tahapan penelitian yang mengacu pada metode perancangan integrasi sistem informasi berbasis service yaitu service oriented analysis and design (SOAD). Service Oriented Analysis and Design (SOAD) ini sendiri memiliki dua tahapan penting yaitu service oriented analysis dan service oriented design, meskipun menyediakan tahapan yang lengkap dalam tahap analysis maupun design, namun SOAD lebih terfokus kearah analisis dan desain dari service dan business process yang akan ada dalam suatu aplikasi dan tidak menyediakan pedoman dalam memberikan gambaran interaksi user dengan aplikasi.

Maka untuk dapat menggambarkan interaksi user dengan aplikasinya sebelum tahapan service oriented analysis dan service oriented design akan dilakukan terlebih dahulu gambaran rancangan interaksi user dan aplikasi dengan menggunakan use case diagram. Setelah selesai tahap analysis service oriented dan 
design service oriented maka digambarkan arsitektur data dari desain service yang sudah diperoleh dengan menggunakan class diagram.

\section{HASIL DAN PEMBAHASAN}

\subsection{Indentifikasi Proses Bisnis}

Untuk memperoleh gambaran proses bisnis yang berlangsung di Politeknik LPKIA maka akan dijelaskan mengenai aktifitas-aktifitas yang dilakukan pada obyek penelitian dengan menggunakan pendekatan Business Process Management (BPM) dengan menggunakan tool Business Process Modeling Notation (BPMN). Berikut ini aktifitas-aktifitas yang dilakukan beserta BPMN.

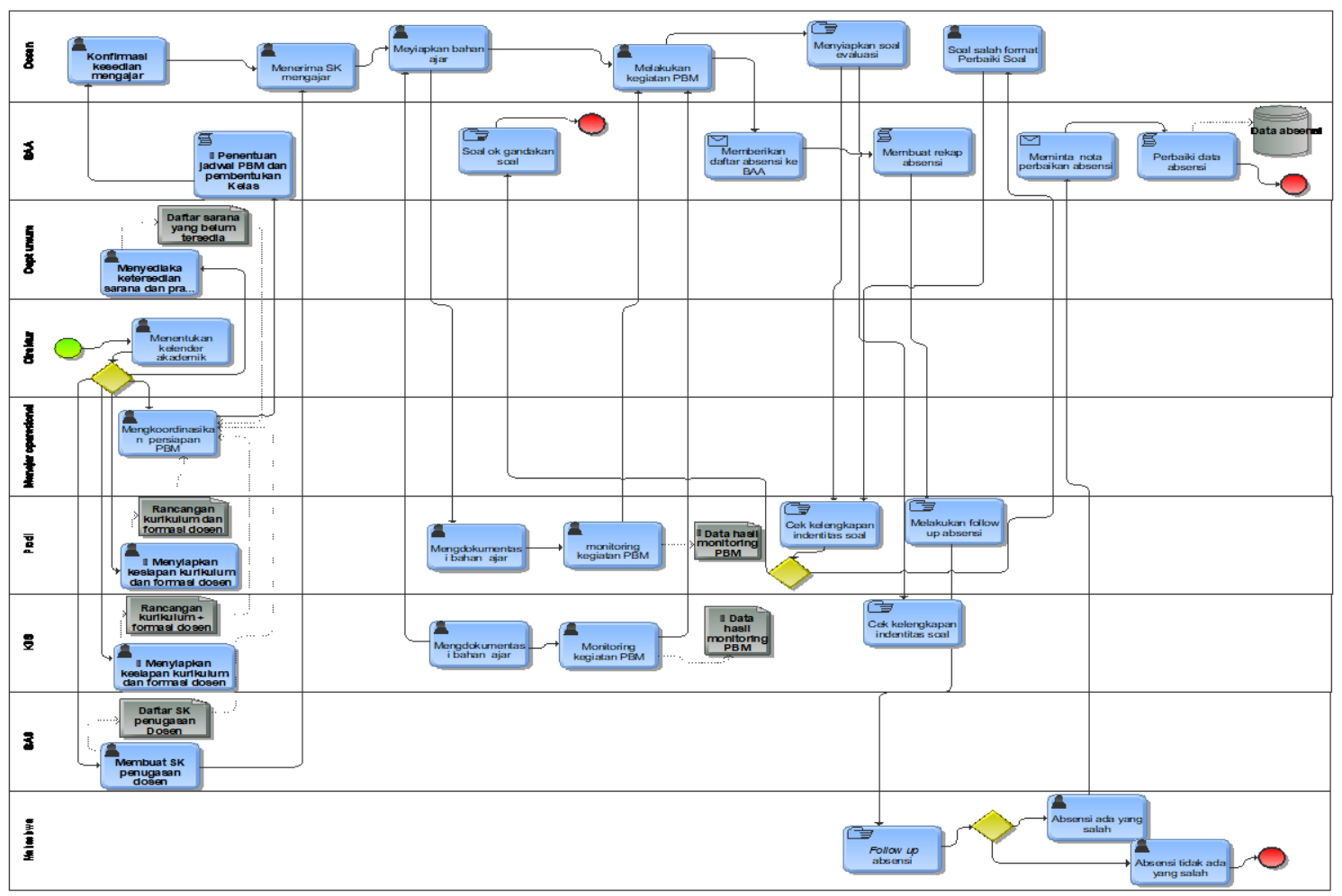

Gambar 2: BPMN Proses Kegiatan Belajar Mengajar 


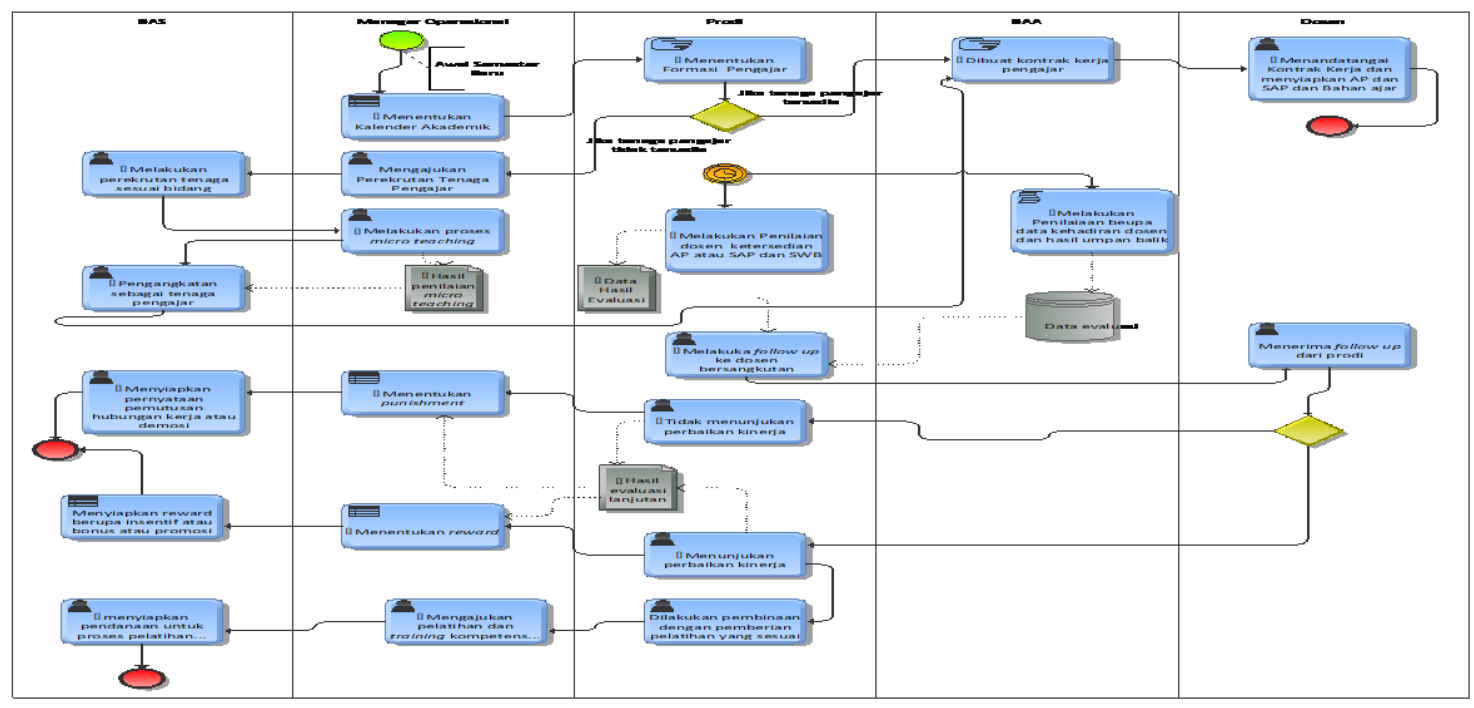

Gambar 3: BPMN Pengelolaan Sumber Daya Manusia

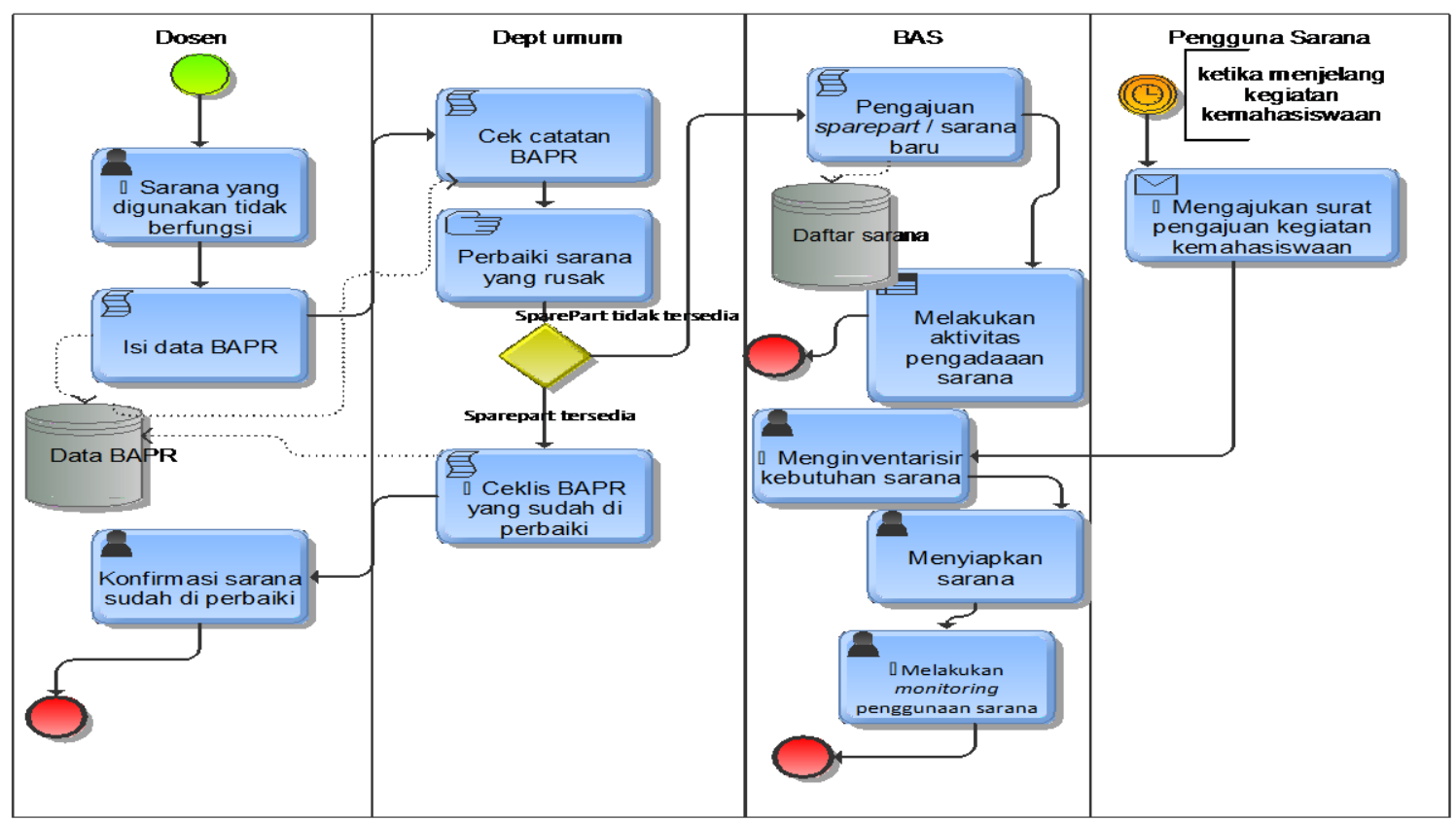

Gambar 4: BPMN Pengelolaan Sarana dan Prasarana

\subsection{Gambaran Existing System Berdasarkan Platform}

Berikut ini (legacy system) berdasarkan platform yang digunakan serta database engine yang digunakannya. 
Tabel 1. Daftar Existing System Berdasarkan Platform

\begin{tabular}{|l|l|l|l|l|}
\hline No & \multicolumn{1}{|c|}{ Aplikasi } & \multicolumn{1}{|c|}{ Platform } & Jenis & \multicolumn{1}{|c|}{ Database Engine } \\
\hline 1 & Evaluasi PBM & MS.Visual Basic & GUI & MS. SQL Server \\
\hline 2 & Kehadiran Mahasiswa & PHP & $\begin{array}{l}\text { Web } \\
\text { Base }\end{array}$ & My SQL \\
\hline 3 & Evaluasi kinerja dosen & ASP & $\begin{array}{l}\text { Web } \\
\text { Base }\end{array}$ & My SQL \\
\hline 4 & Perpustakaan & MS. Visual Basic & GUI & MS. SQL Server \\
\hline 5 & $\begin{array}{l}\text { Penerimaan Mahasiswa } \\
\text { Baru }\end{array}$ & MS.Visual Basic & GUI & MS. SQL Server \\
\hline 6 & Input BAPR & ASP & $\begin{array}{l}\text { Web } \\
\text { Base }\end{array}$ & My SQL \\
\hline 7 & Registrasi dan SPP & MS.Visual Basic & GUI & MS. SQL Server \\
\hline 8 & Penjadwalan & MS.Visual Basic & GUI & MS. SQL Server \\
\hline 9 & Bursa Tenaga Kerja & PHP & $\begin{array}{l}\text { Web } \\
\text { Base }\end{array}$ & My SQL \\
\hline
\end{tabular}

\subsection{Rancangan Usecase Diagram service}

Analisis service kebutuhan informasi ini dapat digali melalui studi terhadap operasional prosedur dan observasi langsung pada obyek penelitian. Pada dasarnya terdapat 5 service utama yang berhubungan dengan operasional systemkan yaitu academic service, financial service, job market service, infrastructure maintenance academic service, library service. Setiap service utama dapat memiliki service lain didalamnya, yang direpresentasikan dengan use case package.

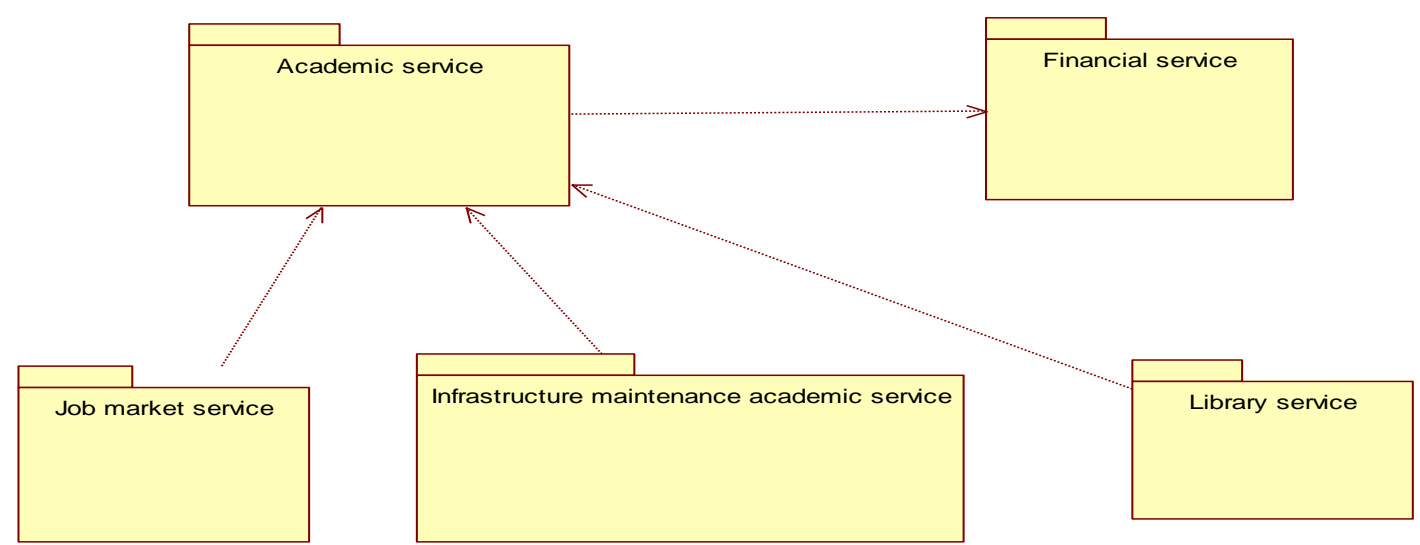

Gambar 5: Service-Service Utama Politeknik LPKIA Bandung

Dari service utama ini kemudian dilakukan breakdown menjadi service-service yang lebih kecil berupa kandidat-kandidat service yang diperlukan oleh para pengguna informasi di Politeknik LPKIA Bandung. Perancangan use case 
memberikan gambaran secara umum interaksi langsung antara user dengan aplikasi. Serta menggambarkan user yang terlibat dalam suatu system informasi, penggunaan use case memfasilitasi dalam menemukan kebutuhan fungsional dan membantu menentukan lingkup system menjadi bagian-bagian yang mudah dimengerti dan dikelola.

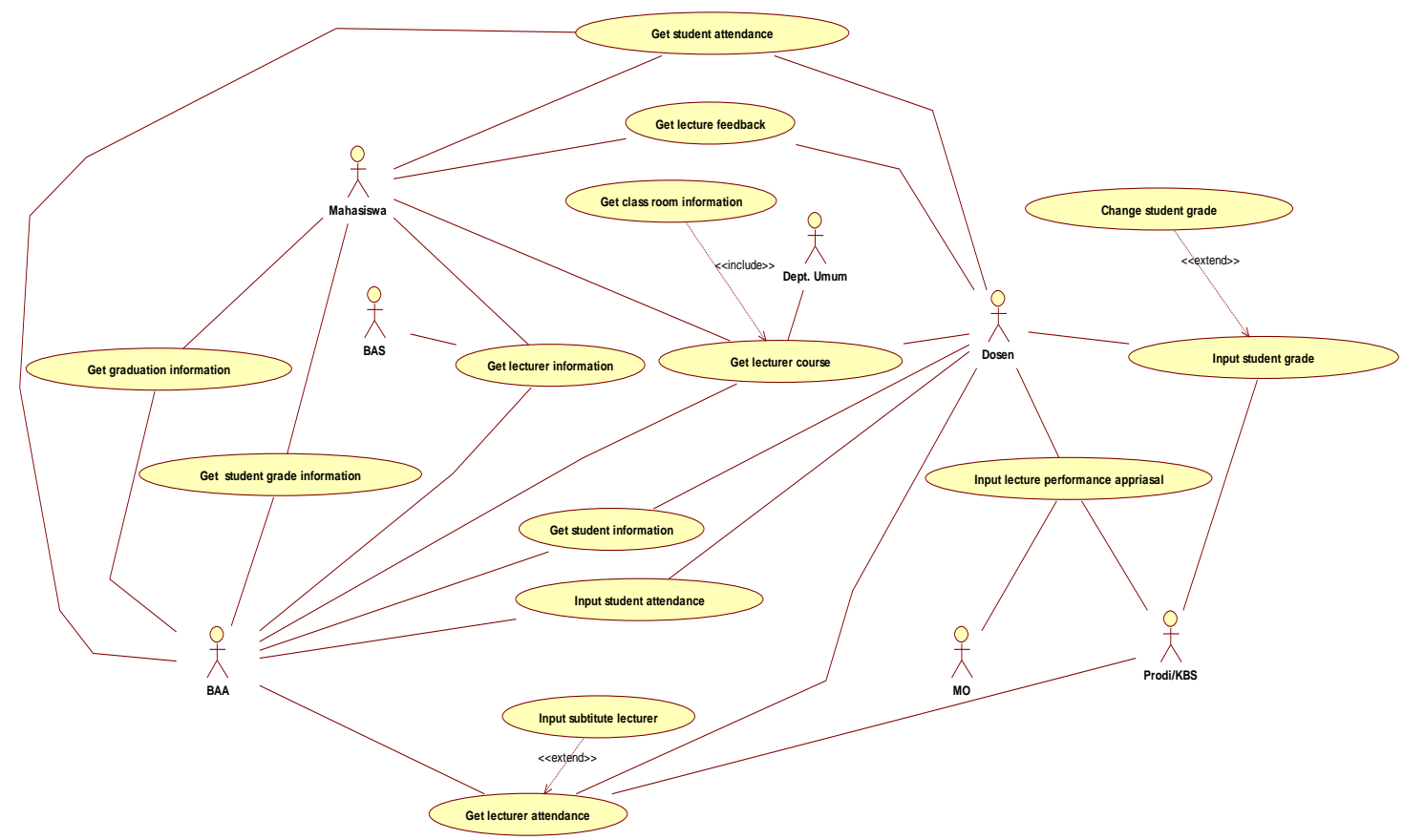

Gambar 6: Use Case Academic Service

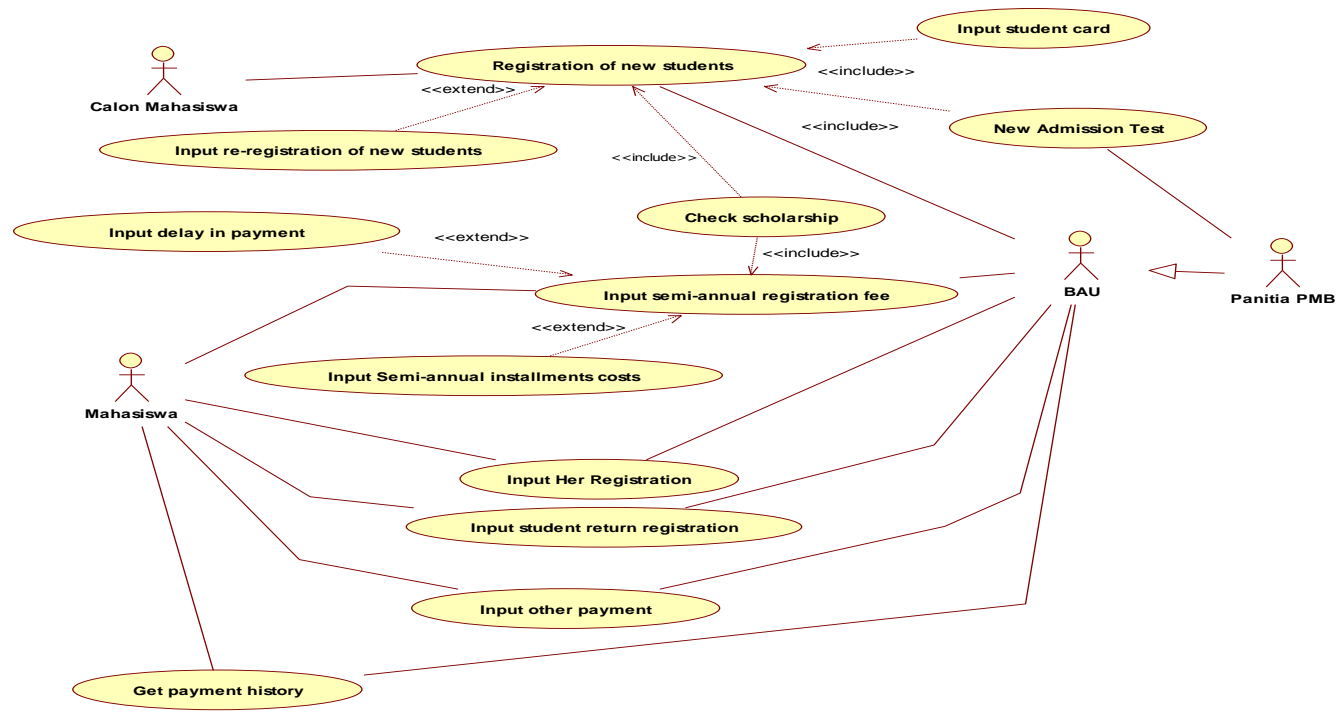

Gambar 7: Use Case Financial Service 


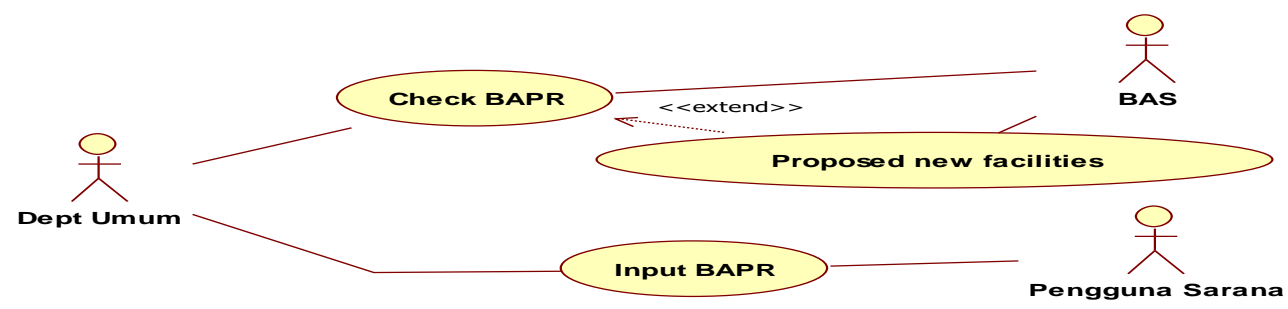

Gambar 8: Usecase Infrastructure Maintenance Academic Service

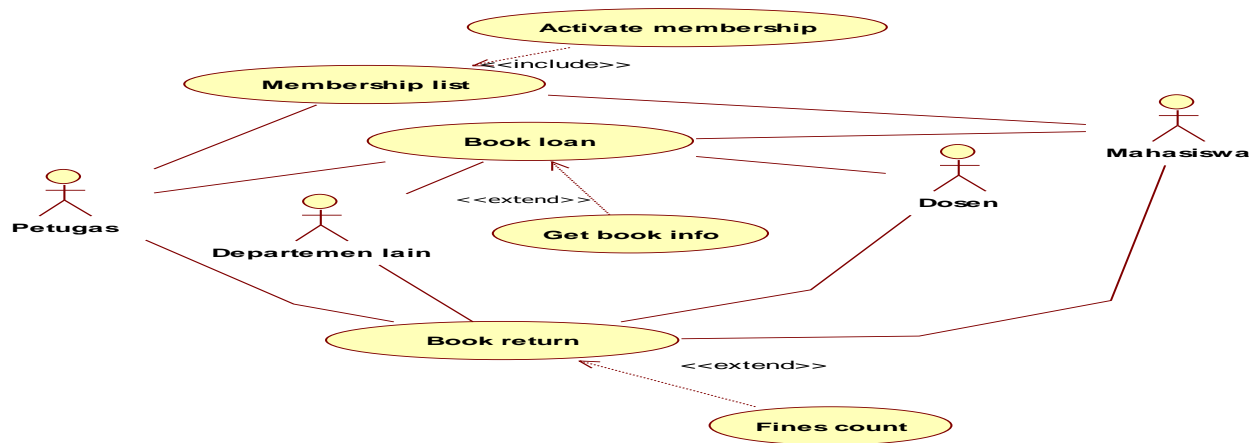

Gambar 9: Use Case Library Service

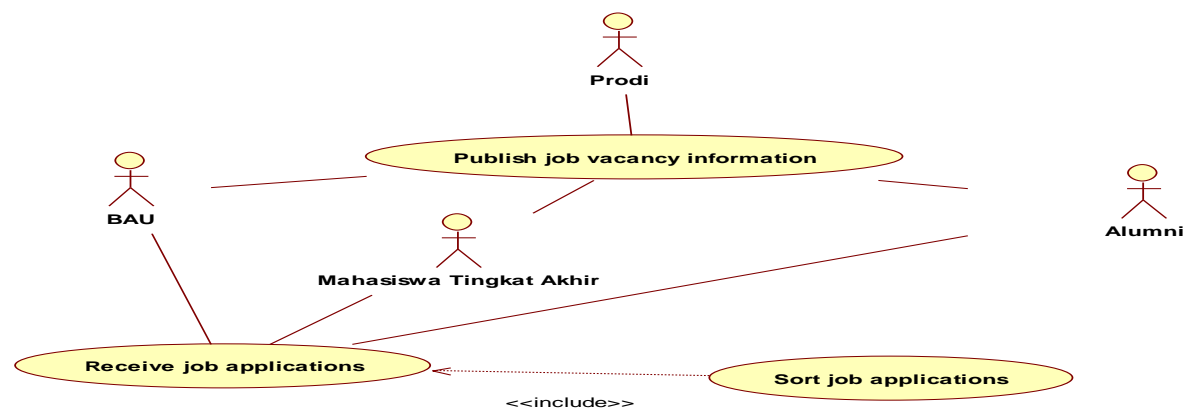

Gambar 10: Use Case Job Market Service

\subsection{Desain Service}

Pada tahapan ini ditentukan desain service final yang merupakan hasil dari proses analisis kandidat service dan kandidat service operation. Yang diperoleh dari analisi dari usecase yang telah dibuat. Yang kemudian menentukan workflow dari service yang sudah dibangun dengan tujuan untuk mengetahui bagaimana service tersebut saling berinteraksi satu sama lain. Jadi dapat disimpulkan bahwa dengan adanya service. Maka aplikasi yang sudah berjalan (legacy system) tidak perlu mengakses langsung pada database. Sehingga ketika dilakukan pengembangan maka tidak perlu menentukan hak akses maupun rule dari user pengguna aplikasi yang berbeda platform terhadap database. Keuntungan lain karena service yang 
dibangun bersifat independent dan loosely coupled maka ketika akan dibangun aplikasi baru meski di platform baru. Tidak perlu membuat dari awal namun bisa memanfaatkan API dari service yang tersedia untuk pengambaranya bisa di lihat dari Gambaran desain service dan gambaran workflow desain service.

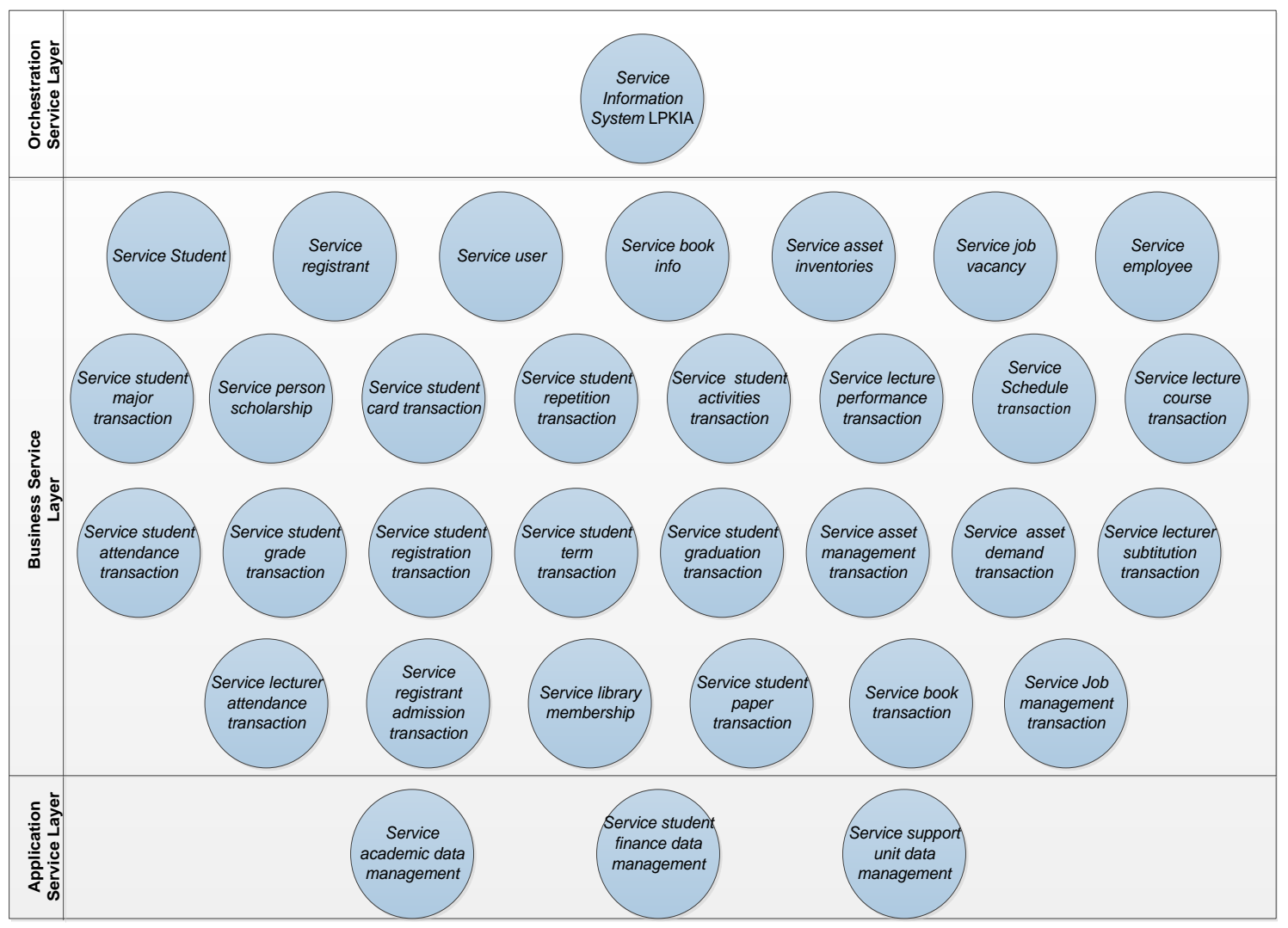

Gambar 11: Desain Service Final 


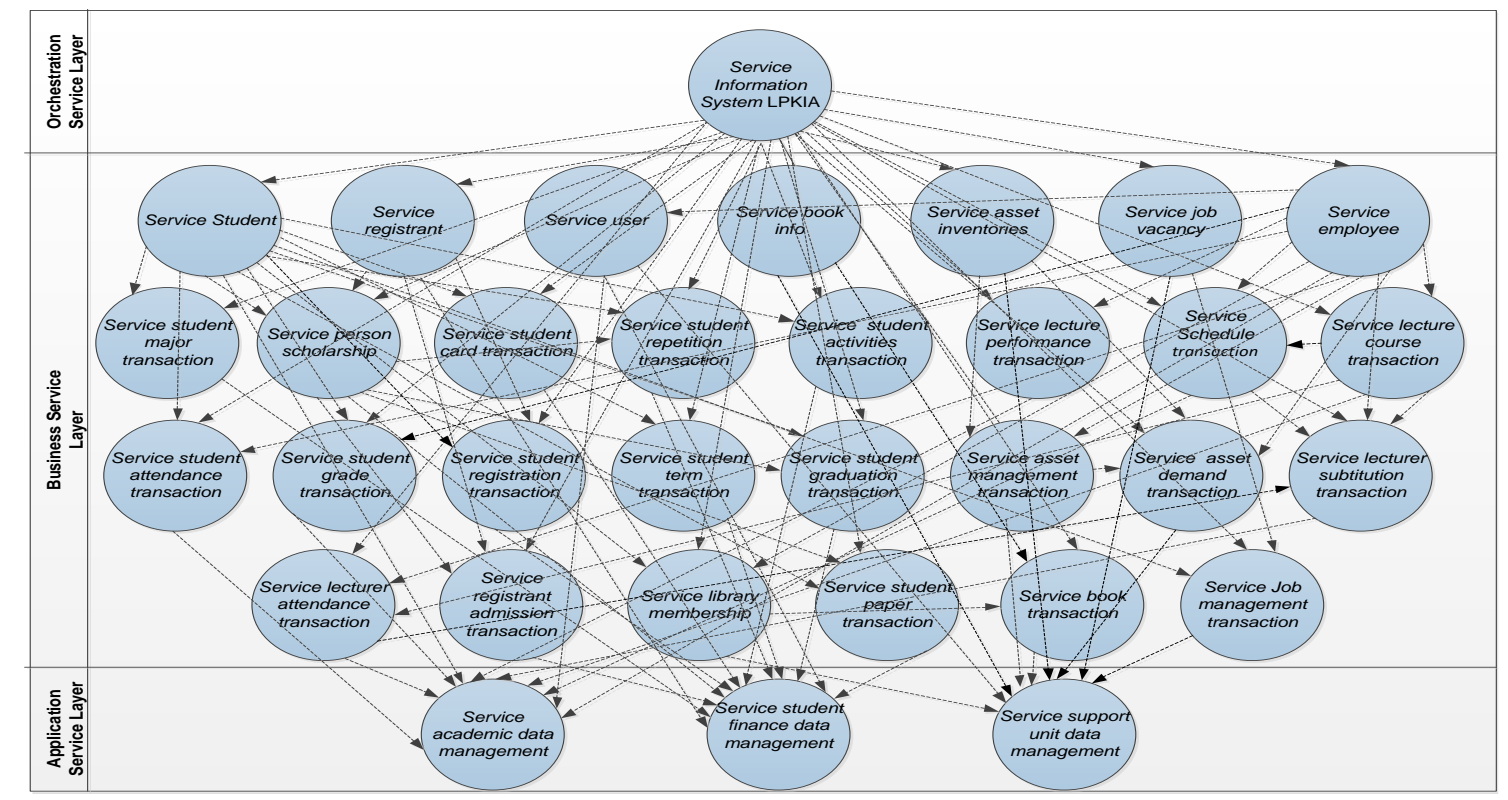

Gambar 12: Workflow Desain Service Final

\subsection{Rancangan Class Diagram Service}

Rancangan class diagram service dibuat dengan tujuan untuk memperoleh gambaran mengenai atribut-atribut pada sebuah service dan service operation yang terdapat dalam sebuah service. Perancangan akan dilakukan meliputi perancangan class diagram untuk academic service, financial service, job market service, infrastructure maintenance academic service dan library service. Dengan adanya rancangan class diagram service diharapkan nantinya memudahkan ketika hasil rancangan yang ada diimplementasikan dalam membangun web service.

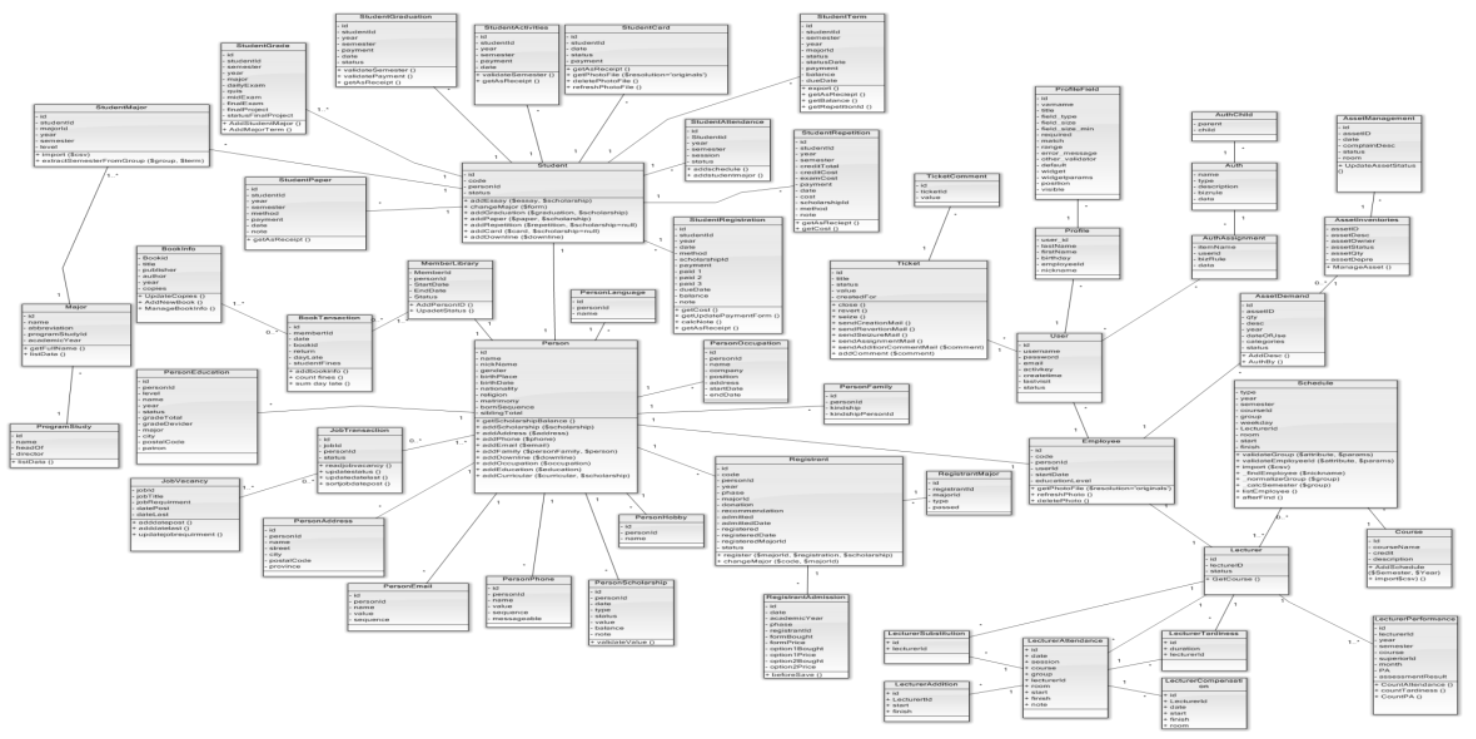

Gambar 13 : Class Diagram Object Politeknik LPKIA 


\subsection{Arsitektur Integrasi Sistem Informasi Politeknik LPKIA}

Setelah dilakukan tahap awal dengan identifikasi proses bisnis yang berlangsung, selanjutnya memetakan existing system atau legacy system. Kemudian dilanjutkan dengan tahap analysis service dengan menggunakan bantuan use case diagram untuk menggambarkan interaksi user dengan aplikasi sehingga diperoleh kandidat service maupun kandidat service operation.

Maka pada tahap akhir digambarkan model arsitektur integrasi sistem informasi di Politeknik LPKIA Bandung. Dapat digambarkan bahwa service merupakan middleware antar legacy system dengan database yang digunakan dengan model seperti ini maka kesulitan perbedaan platform aplikasi dalam mengakses database dapat dihindari Untuk lebih jelasnya gambar model integrasi sistem informasi dapat dilihat pada gambar 14 .

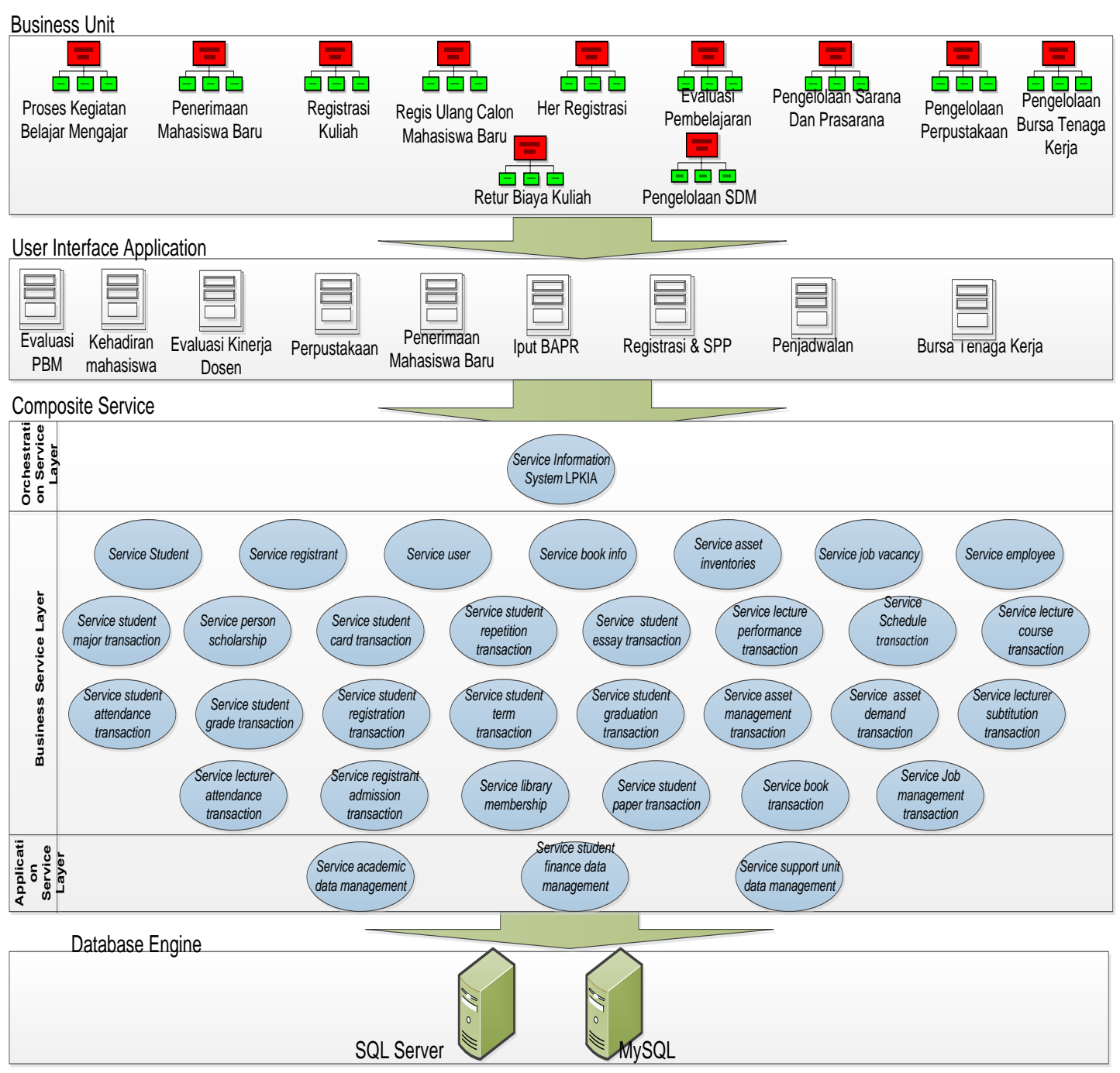

Gambar 14 : Model Arsitektur Integrasi Sistem Informasi Politeknik LPKIA 


\section{SIMPULAN}

Kesimpulan yang dapat diambil dari penelitian yang telah dilakukan adalah untuk memperoleh desain service yang responsive terhadap proses bisnis yang ada di Politeknik LPKIA Bandung, diperoleh desain service dan service operation yang dibagi pada 3 layer yaitu: 1 service pada orchestration service layer, 29 service pada business service layer dan 3 service pada application service layer yang berperan untuk mengakses langsung pada database sehingga diperoleh rancangan blueprint integrasi sistem informasi di Politeknik LPKIA Bandung berorientasi service yang menjadi penghubung (middleware) antar aplikasi berbeda platform Saran yang bisa diberikan setelah melakukan penelitian yang dilakukan Jika akan mengimplementasikan rancangan service maka perlu diperhatikan bagaimana menerapkan integritas dan keamanan data yang akan digunakan dalam tahapan implementasi. Serta menentukan spesifikasi yang jelas bagiamana mengakses sebuah service di platform yang berbeda.

\section{DAFTAR PUSTAKA}

Booch, Grady, James Rumbaugh and Ivar Jacobson. (1998) The Unified Modeling User guide: Addison Wesley.

Erl, Thomas. (2005) Service-Oriented Architecture: Concepts, Technology, and Design: Prentice Hall PTR.

IBM. Patterns: Elements of Service-Oriented Analysis and Design, (2020, April 11) diakses dari http://www.ibm.com/developerworks/library/ws-soad1/

Owen, Martins and Jog Raj. (2003) BPMN and Business Process Management Introduction to the New Business Process Modeling Standard: Popkin Software.

Sarno, Riyanarto. and Anisah Herdiyanti. (2010) A Service Portfolio for an Enterprise Resource Planning: International Journal of Computer Science and Network Security, 145 